\title{
Farm Retailing: Motivations and Practice
}

This paper investigates rural diversification strategies, specifically focussing upon farm retailing. The study reveals farmers' different motivations and experiences of structural diversification through both farmers markets and wholly owned farm shops. Using a qualitative study of eight farm businesses we find that diversification is not always motivated by entrepreneurial objectives. Necessity (push) factors (such as agri-food market inequality) act as the catalyst transforming nascent diversification tendencies. Once the need for diversification is unlocked farmers face an entrepreneurial choice: those with push motivations (such risk reduction) choose non-entrepreneurial diversification in the form of farmers markets; while those with pull motivations (such as business growth) exhibit characteristics of entrepreneurship and engage in entrepreneurial diversification in the form of on-farm retailing.

Keywords:

Farming, Rural Diversification, Scotland, Entrepreneurship, Farmers' markets, On-farm retailing 


\section{Introduction}

This paper investigates areas of opportunity for rural diversification, specifically focussing on farm retailing. The key objectives are to consider farmers' experiences of diversification through both farmers' markets and wholly owned farm shops, examining motivations and drivers. Diversification has a long tradition in farm households, and is a growing phenomenon (Alsos et al, 2003; Clark 2009; Grande et al, 2011; Vik and McElwee, 2011) as farmers have to deal with increasingly competitive economic and environmental conditions (Hingley, 2005).

McNally (2001) suggests that structural diversification through farm retailing is particularly favoured as a means of diversification for small or medium-sized farms due to the minimal investment and processing required for direct sales. There has been some research on rural diversification within the entrepreneurship literature (Alsos et al, 2003; Carter, 2001; Paddison and Calderwood, 2007) but limited exploration of motivational factors for producers focused specifically on farmers' markets or farm shops as consumer facing supply channels.

In this paper we examine farmers' diversification motivations and practices through a qualitative study of eight farm businesses. We find that diversification is not always motivated by entrepreneurial objectives. Necessity (push) factors (such as agri-food market inequality) act as the catalyst transforming nascent diversification tendencies. Once the need for diversification is unlocked, farmers face an entrepreneurial choice: those with push motivations (such as risk reduction) choose non-entrepreneurial diversification in the form of 
farmers markets; while those with pull motivations (such as business growth) exhibit characteristics of entrepreneurship and engage in entrepreneurial diversification in the form of on-farm retailing.

The paper is structured as follows. First we discuss our sectorial context, specifically the key characteristics of the farming sector in general and the Scottish farming sector in particular. This is followed by a discussion of the literature on diversification as a strategic choice. We present findings from our study drawing out implications and suggesting fruitful areas for future research.

\section{Family farms in an agri-business context}

Farming is a critical sector within rural economies (Phelan and Sharpley, 2012) but is uncertain and risky for those reliant upon it (Turner et al, 2003). Structural factors such as dominance in numbers of small-size family farms, inefficient systems and lack of farmer's skill in management have led Meert (2005) to consider that Western Europe faces a chronic problem of farmer poverty which makes dependence upon traditional agriculture unattractive.

The literature has struggled to explain the persistence of family farms (Morell and Brandth, 2007), which are defined as enterprises where ownership and control is in the hands of family and transferred over different generations; labour is provided by the farmer and their family; and a considerable share of household income is derived from farming and the family lives on the farm (Calus and Van Huylenbroeck, 2010). The picture within Scottish farming mirrors wider trends. The majority of farm holdings are small, specialist businesses. Over half of the 
52,626 VAT-registered farm businesses in 2011/12 (52\%) were less than 10 hectares in size (Scottish Government, 2013). Average farm business income was $£ 45,000$, a fall of $6 \%$ on the previous year. However, the majority of farms earn less than this and $9 \%$ of farms failed to make a profit at all. Rural poverty in core agriculture has been linked to inequality in the agri-food supply chain. Hingley (2005: 63) discusses the power imbalance within a supply chain organised and directed by the retailer, "the majority of control lies in the hands of large multiple retailers" and this negatively impacts farmers' outcomes. The agri-food supply chain has consolidated. Retailers have reduced suppliers privileging large industrio-agricultural entities (McElwee and Bosworth, 2010). This 'reduced supplier sourcing model' (Hingley, 2005) affords producers with sufficient scale and sophistication opportunities of preferred supplier status but locks them in a vertically integrated partnership. Hingley (2005: 70) explains that while suppliers benefit from dedicated partnerships with supermarkets, it generates pressure to produce more goods at a lower cost and within tighter time scales, "forever engaged in the vicious circle of efficiency and cost-led competition" which negatively impacts the financial viability of all but the largest farming businesses.

Farm diversification is considered an alternative to traditional production agriculture, a potential solution to low income which doesn't require abandoning the farming enterprise (McElwee and Bosworth, 2010). Diversification is a key theme of EU rural development policy (Hansson et al, 2013) consequently there is support for diversification in national and regional support programmes (Scottish Government, 2013). Approximately half of all Scottish farms (47\%) generate additional income from diversified activities. Average income from such activities is $£ 5,000$, although around a quarter of farms with diversified activities make no profit from these (23\%) (ibid). 


\section{Diversification}

Grant (2010) offers three motives for diversification: to gain competitive advantage; to minimise and manage risk; and to achieve business growth. Diversification is therefore considered an important driver of organizational conduct and performance (Antoncic, 2006). In SMEs diversification allows firms to use their valuable resources to exploit different market opportunities and improve their competitive positions (Fernández-Olmos and DíezVial, 2013).

\section{Farm Diversification}

Farm diversification conversely has been portrayed as a lesser alternative to agricultural production undertaken by a minority without the resources to excel at traditional 'farming' (Clark, 2009). Diversification is the inclusion of non-traditional farm enterprises into the business model (Northcote and Alonso, 2011). The related concepts of pluriactivity and farm diversification have become the focus of a relatively small research literature and of interest as dominant forms of agricultural enterprise development.

Meert et al (2005) consider there are six potential developmental pathways in an agricultural business: industrial model, agricultural diversification, structural diversification, income diversification, reduced farm activity and part-time farming. McElwee and Bosworth (2010) suggest a typology of diversification distinguishing five main forms: reducing the farm holding (selling land or parts of land), property development (retaining but renting land to be run by another party), diversifying into new business activities (deriving from natural resources or not farm related), diversifying the farm business (related to farm production) and diversifying income (pluriactivity). 
This paper integrates Meert et al's (2005) agri-business pathways and McElwee and Bosworth's (2010) diversification typology to develop its research framework. It suggests that there is a need to focus within these models upon distinct diversification types since farmer's experiences of these are considerably different. It chooses to focus upon diversification of the farm business (McElwee \& Bosworth, 2010) because this form of diversification best retains the core characteristics of a family farm (Table 1). Farm business diversification ensures that business control remains within the family, income is related to farming and the family continues to live on the farm (Calus and Van Huylenbroeck, 2010).

\section{Insert Table 1 about here}

This study focuses upon structural diversification (Meert et al, 2005: 84) including activities such as "farm gate sales, sales at farmers' markets, on farm processing and farm tourism". It does so because this form of diversification is particularly attractive to farmers, and is considered by them to offer good business outcomes (Farmers' Guardian, 2013), yet it requires distinct entrepreneurial skills (Carter, 1999). It considers how farmers decide between competing structural diversification forms. This understanding is critical since whilst structural farm business diversification may be seen as an appropriate response to rural restructuring the outcomes deriving from diversification choice may be considerably different and McNally (2001) considers that farmers will vary greatly in both ability and motivation to achieve such diversification.

Structural diversification has become increasingly common on UK farms driven by decline in farm incomes alongside a lack of alternatives to remaining on the land (Scottish Government, 2013). McNally (2001) suggests that structural diversification through farm retailing such as farm shops, 'pick your own' schemes and selling at farmers' markets is 
particularly favoured as a means of diversification for small or medium-sized farms due to the minimal investment and processing required for direct sales. Diversification is argued to require the farmer to behave more entrepreneurially (McElwee and Bosworth, 2010) and a central issue addressed here is whether diversification activity can be thought of as entrepreneurial.

\section{Farmer's Markets and On-Farm Retailing}

As noted above, McNally (2001) has identified farm retailing as a particularly common form of farm business structural diversification which cultivates "shorter supply chains that bring consumers face-to-face to with producers" (Eden et al, 2008: 2). One branch of farm retailing is farmers' markets which have experienced a recent and rapid growth. It is difficult to determine exact numbers as the distinction between markets and farmers' markets can be difficult to ascertain. Estimates are that they have increased in number from 59 in 1999 to 600-700 now operating across the UK (Mintel, 2014).

Kirwan (2006) identifies two aspects common to farmers' markets. First, all produce sold at these markets must be local in its origin of production. Second, vendors at the market should have been directly involved in the production of the goods sold. Much of the research on farmers' markets has focussed upon the consumer experience. Hinrichs (2000: 297) notes that markets provide access to "fresh, high-quality farm products at reasonable prices" and La Trobe (2001: 183) that compared to large supermarkets "farmers' markets offer consumers a more enjoyable shopping experience". Hinrichs (2000: 295) concludes that farmers' markets are particularly favoured by consumers because they "promise human connection" missing in contemporary consumerism. These markets have been considered in the scant literature to have several benefits for smaller farmers. Those who sell at famers' markets are argued to be 
able to acquire nearly $100 \%$ of their consumers' food spend and to benefit indirectly through increased jobs and incomes as a result of increased locally grown food consumption within communities (Conner et al, 2010).

A similarly common, though more capital intensive, form of farm retailing is to invest in on-farm retail capacity in the form of farm gate sales, pick your own and farm shops. While traditional strategic literature may consider this vertical integration, adding value to products and satisfying the needs of particular customers means they can legitimately be considered diversification (Hansson et al, 2013). Despite the popularity of these forms of structural diversification there is little research supporting farmers in understanding the implications of their enterprises. This research seeks to address this gap by exploring the experiences of farmers engaged in both these common structural diversification strategies.

\section{Methodology}

This study uses case studies to explore farmer perspectives on diversification and provide a degree of contextual explanation (Yin, 2008). Case studies are suited to studying contemporary, real life, complex phenomena (Yin, 2008) and within entrepreneurship have been identified as particularly relevant forms of investigation (Zahra, 2007). They provide tools to investigate phenomena within their natural context, and thus elicit detailed explorations (Hoaglin et al, 1982). Huberman and Miles (2002: 1) consider case studies to be a comprehensive research method, as they "preserves chronological flow, see precisely which events led to which consequences, and derive fruitful explanations". 
Scottish farming was chosen for our empirical study for three reasons. First, reflective of UK agriculture, this is an industry with a high proportion of small family businesses. Over half of all Scottish farm holdings are less than 10 hectares and $85 \%$ of farms outside of dairy and general cropping employ less than one FTE (Scottish Government, 2013). Second almost half of Scottish farms gain income from diversified activities (ibid). Finally, using snowball and judgment sampling, researchers were able to exploit the small and well-connected nature of the Scottish farming community to access key informants. Using guidelines provided by Yin (2008), 8 farming businesses were selected from within the Scottish farming community. Meeting the study's requirements, respondents' businesses covered a range of SME farming forms (as identified by the Scottish Government (2013)) and possessed diversification characteristics. Following Clark (2009), all the businesses were family-owned and managed. Fieldwork was situated in South west and South east regional groupings (Scottish Government, 2013) specifically Argyll and Bute, Ayrshire, Clyde Valley, East Central and Lothian. Potential farms were identified from the researchers' own farming networks and additional recruitment at agricultural events such as the Royal Highland Show, agricultural markets and farmers markets between 2012 and 2013. These were then screened for appropriate diversification strategies using Clark's (2009) typology of six on-farm entrepreneurial characteristics focusing upon the three most relevant to this study: adoption of a new market orientation, capitalising on endogenous resources and new forms of governance, in order to generate the final sample (Table 2).

\section{Insert Table 2 about here}

Information was gathered using observations in diversified retail at farmers' markets and onfarm shops. Researchers spent time with the farmers observing both their diversified retail and core farming activities. In total 14 interviews were conducted both on farm and in farmers' markets with the farmers (defined by Clark (2009: 219)) as "the person responsible for 
administration of the business, including diversified activities", covering a main interview and a follow-up visit where available. Additionally observations and informal conversations with other members of the farm household in both locales informed analysis. Both researchers have agricultural and food industry research experience and so come informed to the field, however observations helped further contextualise the business situation, clarify understanding of farmers' practices and validate farmers' accounts of the outcomes of diversification. Interviews were semi-structured focusing upon motivations for diversification, necessary practices and exploring farmer's interpretations of the outcomes of different approaches while probing interesting responses as these emerged (Patton, 2002). Interviews used a funnelling approach beginning with general discussion of farmers' lives and history of their farming businesses before a more focussed discussion on diversification activities. Interviews of between 45 minutes and 1.5 hours were audio-recorded to allow "conversations to flow, eye contact to be maintained and interaction to occur" (Wilson, 2012: 108). After each interview the researchers discussed initial impressions and observations, taking notes to crystallise the main themes emerging (Bryman and Bell, 2003). Analysis compared commonalities and differences in participants responses and perceptions as these related to emerging themes (table 3).

\section{Insert table 3 about here}

Three broad themes emerged and act to structure our discussion of findings. First we consider the motivations for structural diversification and specifically suggest that in all investigated cases an underlying necessity-driven motivation was evident (Schjoedt and Shaver, 2007). We then distinguish between structural diversification forms. We suggest that rather than homogenous in motivation, practice and business outcome (Zerbe, 2010) there are two distinct typologies: (1) non-entrepreneurial structural diversification evident in farmers' markets and (2) entrepreneurial structural diversification evident in on-farm retailing. 


\section{Push Motivations for Diversification}

Schjoedt and Shaver (2007) suggest that nascent entrepreneurship is motivated by pull factors such as business growth however in our data this wasn't initially evident. Rather, as Hansson et al (2013) discuss, necessity driven push factors dominated. All participants had experience of the mainstream agri-food systems, with their produce being sold to one of the major UK supermarkets prior to diversifying, and had experienced three major areas of dissatisfaction which had driven their diversification: poor income, power inequality, and risk and waste.

\section{Poor income}

While traditional agri-farming delivers some certainty by guaranteeing a buyer this doesn't translate a certainty of income as a result of preferred buyer status. In discussing their withdrawal from traditional agri-food supply chains respondents considered that the supermarkets used macro factors to their advantage in negotiating terms:

'With welfare standards being so strict here compared with other countries in the EU, supermarkets just bought from abroad rather than pay British farmers more money. We want to produce a quality item but you need to get the margin...[Being free-range] obviously meant our costs went up and so we had to pass these onto the supermarkets but they weren't having any of it so they bought from abroad.' (John)

Both livestock and arable farmers considered that in the traditional agri-food system the supermarkets have the control and farmers are largely powerless. Farmers commented that little negotiation takes place between farmers and supermarkets since, if supermarkets don't agree with the price farmers suggest, they will find someone who can offer them better prices and credit terms. Kathy 
a beef farmer discussed her feeling of powerlessness within the system after health scares in the market:

'we've been farming since 1984 and dad was farming before us so we've been doing it for a long time...And then when it was Foot and Mouth time, we got quite annoyed because the supermarkets took advantage of the situation and they just wouldn't give us any money and they were just taking the mickey really, the slaughterhouses were taking the mickey and they wouldn't pay what we felt we were due...they took advantage of it and got it into the supermarkets cheap.'

\section{Power inequality}

Respondents also reflected other disadvantages to working within the agri-food supply chain which have been identified in the literature. Alistair though broadly happy with his relationship with his major supermarket customer described the resultant business requirement:

'[They were] saying we want a little bit more and then you've got to do it, got to comply with this, now you've got to look at sealing and packaging. Every year you're spending more money on it but the returns were remaining static.'

Hingley (2005: 70) touches on this subject and uses the reduced source model to describe how farmers can find themselves on an "operational innovation treadmill to oblivion". This occurs when supermarkets select preferred suppliers and force them to produce larger quantities of more high quality produce at a lower cost.

\section{Risk and waste}

Hingley (2005) suggests that whilst being a supplier with preferential status can provide short-term gains for farmers; the conditions which are forced on them by the supermarkets could mean they are 
ultimately forced from the chain. This was the experience of the other soft fruit farmer in the study Helen:

'We're actually soft fruit growers... we used to work with the supermarkets and we didn't really like it... the low prices was one reason we came out of it but the supermarkets just didn't want second class fruit. They screen it and study it and if the fruit is found to have any blemishes or defects they reject it straight away and we're left with what they don't want which is actually perfectly fine to eat but maybe just isn't what the supermarkets think looks perfect.'

Respondents considered that this disadvantaged position in the supply chain had led them to diversify so they could be more in control of their business. Schjoedt and Shaver (2007) in considering the factors which transform nascent entrepreneurs into active entrepreneurs suggest that opportunity driven factors such as business opportunity or business growth are more motivational than necessity driven factors such as security. Respondents to this study sat contrary to this theory however focusing at the primary level upon the necessity driven inequity in traditional agri-food systems as the key catalyst driving their decision to engage in structural diversification.

The range of structural diversification forms are often considered homogenous. A set of alternative food networks offering very general insights and broad-level assessments (Maye, 2013). In our early observation in farmers' markets and farm shops we began to question this homogeny and our interview data shows that structural diversification forms are quite different. Farmers' markets while popular with farmers were found to take push or necessity motivations to extremis such that farmers' diversification motivations, practices and business outcomes could not be identified as entrepreneurial. On-farm retailing conversely represented a balancing of push (necessity) / pull (opportunity) motivations for diversification. Farm shop diversification demonstrated both entrepreneurial business characteristics and consequent farmer skills. 


\section{Non-Entrepreneurial Diversification Characteristics in Farmers' Markets}

Farmers' markets were considered to be the most consumer recognised form of structural diversification and to have advantages over other forms by providing ready access to an attractive and established market while not being far removed from farming activities.

\section{Access and ease}

Farmers' markets, as the literature suggests, are numerous in the UK and the researchers spent time in ten different markets observing farmers' practices. Over our two year data collection period we visited markets during weekends and mid-week; in urban, suburban and rural settings; and across the seasons. McElwee and Bosworth (2010) have suggested that for diversification to be considered entrepreneurial it should contain three dimensions: risk taking, growth orientation and innovativeness. These characteristics were absent both in our observations and in the interview accounts of farmers' markets participants. Farmers' markets were inherently risk minimising, primarily considered as a good source of incremental income keeping cash-flow healthy during the quieter winter months: 'Well we're here so we can sell what we grow, the farmers' markets are good for keeping us going through the winter when we're less busy.' (Bill). Necessity rather than growth emerged dominantly as a driver of farmers' market diversification (Schjoedt and Shaver, 2007); satisfying income needs across the businesses as a whole (McInerney and Turner, 1991): 'Some time ago when the supermarkets were squashing their prices really flat, well, it was a backlash. The farmers' said 'we'll do it ourselves' but it's really a protest.' (John). Farmer's markets tend to act as an easily accessible form of diversification for those without inherently innovative businesses: 'we like the farmers' markets 'cause we can keep a focus upon the traditional farming work and just fit this in around the core business.' (Tom) 


\section{Poor risk evaluation and outcomes}

In detailing their practices, farmers' exposed a key contradiction between motivation and practice. Farmers identified income risk minimising motivation for diversification through farmers' markets. However it emerged through their practices that because these are such a readily accessible diversification form farmers often underestimated their true effort and costs: 'It's a big effort to do this, this is hard work. It takes us an hour to set up and another hour to take it down and put it in the van. We had a real crisis one Christmas where we seemed to have made money and then it got to March and I thought 'where's the money going? We were just losing money.' (Kathy)

We were able to assess the effort and cost involved in participating in these markets. At one suburban farmers' market which we visited with Farmer Will in late February we watched farmers setting up at 7.30am yet customers didn't trickle in until mid-morning, burgers grilled to entice absent customers were passed among the other stallholders and little money changed hands.

This underestimation of the true costs of doing business within farmers' markets was also evident in a number of the interviews and contributes to distancing farmers' markets from entrepreneurship. Risk evaluation skills are argued to be inherent within successful entrepreneurs (Welpe et al, 2012) and we found these skills to be largely absent in our farmers' market participants. Joe participates in a number of farmers markets and recognises that there are some which are not income generating yet he continues attending saying:

Joe: 'There is one market and it just gets junkies [drug addicts]. No right minded family would come-so it's not really worthwhile'

Researcher: 'Why do you keep going?' 
Joe: 'What else would we do? This is our only chance and you just hope it'll get better.'

Joe's diversification was driven by necessity. This was due to a lack of viable business alternatives and continual income shortfalls. This meant that, rather than behaving entrepreneurially, he endures in unprofitable practices in hope of a brighter future.

A second contradiction, between motivation and business outcome was evident around the issue of risk minimisation. McInerney and Turner (1991: 407) argue that "diversification can help avoid cyclical [or episodic] fluctuations of profits" and as discussed informants had identified this as a key motivational factor for their farmers' market participation. However, informants suggested that farmers' markets were not an effective form of diversification in managing either cyclical or macro risks. Farmers' markets themselves were also found to suffer from the seasonality farmers sought to avoid: 'We decided to stop the farmers' markets we were finding that we were just selling little bit sof jams and chutneys throughout the year, soft fruit during the summertime and it was a bit hit or a miss and if you took the labour element into it then it wasn't really worthwhile.' (Helen). Weatherall et al (2003) suggest that farmers' markets harness consumers who are seeking to buy local produce to counteract the effects of globalisation on the agro-food system. Hinrichs (2000) and La Trobe (2001) discuss quality, value and shopping experience as drivers of their popularity. However in considering business outcomes the farmers recognised that farmers markets' popularity and profitability were impacted by macro-economic conditions which reintroduced risk into this form of diversification: 'Now, people are more conscious about what they're spending and for all their good intentions it doesn't help the farmers standing here selling. And when farmers' markets started maybe people thought it was a nice day out coming to see what farmers were selling, but now supermarkets win out because people can get everything they need in one place. The bottom line is people spend with their purses.'(John) 
Informal conversation with the farming households garnered much concern about the future of farmers' markets, how consumers may react to an enduring economic downturn and whether authentic experience was a luxury many shoppers could afford.

Our findings show that farmers' practices within farmers' markets do not constitute entrepreneurial behaviour or skills (McElwee and Bosworth, 2010). Farmers rather use farmers' markets as a risk minimising strategy and we would argue exhibit satisficing behaviour (Simon, 1959). The reality is that they do not account for many of the risks associated with this activity underestimating cost, time and impact upon their core agricultural business. What we then see is a retrenchment because of lack of overall business integration back to the core agricultural business where the underlying agri-food problems continue to exist.

\section{Entrepreneurial Diversification Characteristics in Farm Shops}

Farm shops as the other dominant form of structural diversification were more popular for those with requisite resources and more resonant of entrepreneurship. Returning to McElwee and Bosworth's (2010) entrepreneurship dimensions of risk taking, growth orientation and innovativeness, diversification through farm shops was more satisfactory in fulfilling the characteristics of entrepreneurial activity.

\section{Investment and good risk evaluation}

On-farm retailing was identified by informants as substantially higher risk than other forms of structural diversification because of the initial and ongoing investment requirements. 
'The cost is certainly a reasonable capital expenditure, especially being a tenanted farmer, you don't have many assets so we were quite lucky that we were able to finance the initial build and then the extension. It's quite a laborious process, filling in all the forms and waiting for them to consider it...'(Alistair)

Alistair also discussed that coupled with the set up costs there was an additional risk taken by farmers in diversification. Because of widespread recognition of the variability of farming income and market fluctuations he identified that traditional farming has safety nets which mitigate the risk to farmers in the form of subsidies. He suggests that in a diversified business this same support is not available opening the farmer to a new set of risk factors.

'I mean if you make mistakes it's more painful whereas if you're farming more conventionally there's quite a lot of safety nets to help you in bad years. If we get it right, we see the benefits of it but if we get it wrong, we feel the pain.'

This farmer has continued to behave entrepreneurially towards risk seeking incremental finance and extending his offer further from his core agricultural business by taking advantage of what he considers to be his market attractiveness; developing family activities and a café in addition to his farm shop and expanding the appeal of his diversification. Alistair exhibits strong risk evaluation skills. He suggests that his diversified farm activities such as farm shop and cafe have helped him to manage his overall business risk by providing more stable forms of year-round business.

\section{Good risk outcomes and growth}

The increased risks associated with these entrepreneurial diversifications were considered worth exposure because they can lead to the satisfaction of the second of McElwee and Bosworth's (2010) entrepreneurship dimensions; business growth. Half our sample had on-farm shops in which we were 
able to conduct observations. In each there were aspects of the shop which the farmers had earmarked for change or expansion. One of our informants Helen, considering her motivation for on-farm retailing, identified growth as her main driver: 'We're only at 320 acres, it's too small really to get a good income for the family.... So the retail side of the business developed and we made the decision to build the new farm shop we doubled the size two years later so that's how we got to where we are today.' In keeping with the literature this farmer continued to have 'dynamic and competitive economic striving, in continuing pursuit of opportunity' (McElwee and Bosworth, 2010: 827) as part of her business strategy. Determining her growth strategy she considered that this would encompass both her traditional farming and diversified business as a unified whole. She said: 'We had 1600 customers on our database and a $60 \%$ response rate and $13 \%$ said they would visit more for organic produce that would give good year on year boost to our farm shop so is in our future plans.'

\section{Innovation}

Finally within McElwee and Bosworth's (2010) entrepreneurial characteristics on-farm retailing was associated with innovativeness of business practice. Literature suggests that some farms by their characteristics find diversification easier and more successful. One of our farmers, John, has a poultry farm which through our observation we can attest would make a difficult consumer experience. His farm was the least attractive (of our sample) for on-farm retailing:

'We only have a small farm, about 135 acres...we could say come and have a look at the farm, it's a lovely spot, come and take the kids for a walk, come and feed the chickens for me... the problem that you find on a busy farm. Because we run the abattoir, the abattoir's not the nice side. '(John)

So John considers that while larger arable farms have the scope to develop their retail and leisure offerings on-site both the compact size and less than idyllic nature of his farming practice in poultry farming means that this wouldn't practically deliver a quality countryside experience. John however 
hasn't been deterred by these shortcomings establishing two innovative strategies to deliver business growth: the establishment of a farm shop within the nearby town and a delivered box scheme.

'We couldn't bring people to us so we had to go to them, we've got a wee high street shop and it's got all our produce and we get from other farmers too and that drives the box scheme; people know us and we've got the network already. It's really the big bit of our business and keeps the unsightly stuff out of sight.'

Visiting John's town shop we observed use of this innovation to keep his business family run and locally relevant. Others too discussed how through using delivery schemes and virtual online farm shops they achieved growth by providing a compelling consumer experience of their farms online.

Phelan and Sharpley (2012) consider that in addition to engaging in entrepreneurial practices entrepreneurial farmers need to develop distinctly entrepreneurial skills. They identify customer service, marketing and financial management as key skills for successful diversification. Farmers discussed how the development of their skills is necessary as their business develops to avoid a capabilities gap. Alistair reflects upon the rapid development of his capabilities through his diversification experience: 'The main hurdles were lack of experience - how to manage staff, the cafe element of things was new to us so food service was a new skill we had to learn. That's the stage where we became more professional'.

\section{Conclusions}

The aim of this study was to explore structural diversification within the Scottish farming community. While diversification is generally considered to be a desirable business strategy alleviating farmer poverty and restructuring rural economies there is relatively little literature considering farmers' experiences of diversification. Structural diversification through farm retailing is 
popular since it satisfies farmer demand to stay on the land and so this was considered the most appropriate diversification context for this study. We suggest two key findings which make contributions to theory: that diversification is motivated by dissatisfaction push factors and that structural diversification isn't homogenous but can be distinguished by considering entrepreneurial characteristics. In situating our first contribution we find our data to be contrary to extant entrepreneurial literature which suggests that nascent entrepreneurship is activated primarily by pull factors such as desire for business growth (Schfoedt and Sharer, 2007). We find that, in pursuing any form of farm retailing structural diversification, all farmers are activated initially by an overriding push factor of dissatisfaction with traditional agri-food systems and the inequality this is considered to bring to the farming experience. In our second contribution we advance Vik and McElwee's (2011) conclusion that there is diversity of motivations for farmers' entrepreneurial diversification. We find that diversification though outwardly entrepreneurial in appearance is not necessarily motivated by entrepreneurial objectives. Rather necessity (push) factors of agri-food market inequality and consequent farmer powerlessness act as the overriding catalyst transforming nascent diversification tendencies. Once the need for diversification is unlocked farmers face an entrepreneurial choice: those with continuing push motivations (such as risk reduction) choose non-entrepreneurial diversification in the form of farmers markets; while those with pull motivations (such as business growth) exhibit characteristics of entrepreneurship and engage in entrepreneurial diversification in the form of on-farm retailing.

In conclusion, despite structural diversification requiring farmers to engage in traditionally entrepreneurial activities their motivations, practices and business outcomes help determine whether they are truly entrepreneurial undertakings. As Timmons (1999: 27) asks does the business have the requisite "ways of thinking, reasoning and acting which are opportunity obsessed?" We suggest that the answer to such questions lies in distinguishing between structural diversification forms. Whilst farm retailing has traditionally been considered to be a homogenous set of activities (Maye, 2013) our farmers' experiences show that the motivations, practices and outcomes inherent in different forms 
distinguish them as entrepreneurially distinct. Farmers' markets we would contend do not constitute entrepreneurial activity because they lack a number of key attributes of the entrepreneurial experience. Entrepreneurs have been considered to have skills which focus upon risk evaluation and strategic awareness but our data shows that both of these dimensions are absent within the farmers' market experience. Farmers engaged in this activity showed their underlying drivers of diversification were to stabilise their business and minimise risk, not inherently entrepreneurial factors. This paper also contributes to our understanding of the requisites of farmers' markets as a continuing diversification channel. Farmers' markets were found to be decreasing in popularity with farmers. This was due to their inability to deliver business outcomes in keeping with farmers' key motivations of increased income, control and seasonal/cyclical stability. Farmers suggested hidden costs and the impact of economic and seasonal macro factors seriously reduced desire to engage in this type of diversification activity.

Farm shops as the other dominant diversification form are performing better by matching business outcomes with farmers' entrepreneurial motivations. This makes them an attractive form of diversification outweighing their higher entry barriers and ongoing business risk. Indeed farmers showed ingenuity in adapting their farm shop practices to extend into online environments in support of their view of physical and virtual on-farm controlled shops as the future of rural diversification.

As with all case-study research our findings are only representative of the firms within our study and we realise that generalisation beyond their experience is difficult. However we consider that we have deepened the conversation on diversification by suggesting there is a need to understand the nuances within commonly conceptualised diversification forms. We argue that understanding business motivations for engaging in diversification is critical to developing a view of the types of entrepreneurial behaviour inherent within farm diversification practices. We have chosen to focus upon different forms of farm retailing as our context because of their popularity among farmers as an 
initial diversification strategy; however following McElwee and Bosworth's (2010) typology of farm diversification we suggest there is need for further research to discuss motivations, practices and business outcomes within related diversification strategies. We also suggest that diversification needs to be understood as a processual entity and that farmers' motivations and outcomes may develop and be better understood by clarifying this process. 


\section{References}

Alsos, G., Ljunggren, E. and Pettersen, L.T. (2003), 'Farm-based entrepreneurs: what triggers the start-up of new business activities', Journal of Small Business and Enterprise Development, Vol 10, No 4, pp 435-443.

Antoncic, B. (2006), 'Impacts Of Diversification And Corporate Entrepreneurship Strategy Making On Growth And Profitability: A Normative Model', Journal Of Enterprising Culture, Vol 14, No 1 pp 49-63.

Bryman, A. and Bell. E. (2003), Business Research Methods, Oxford University Press, Oxford.

Calus, M. and Van Huylenbroeck, G. (2010), 'The persistence of Family Farming: a review of explanatory socio-economic and historical factors', Journal of Comparative Family Studies, pp $639-660$.

Carter, S. (1999), 'Portfolio entrepreneurship in the farm sector: enterprise and employment contributions of farmers in Cambridgeshire', Journal of Rural Studies, Vol 15, pp 417-429.

Carter, S. (2001), 'Multiple business ownership in the farm sector: differentiating monoactive, diversified and portfolio enterprises', International Journal of Entrepreneurial Behaviour and Research, Vol 7, No 2, pp 43-59.

Clark, J. (2009), 'Entrepreneurship and diversification on English farms: Identifying business enterprise characteristics and change processes', Entrepreneurship \& Regional Development, Vol 21, pp 213-236.

Conner, D., Colasanti, K., Ross, R.B. and Smalley, S.B. (2010), 'Locally grown foods and farmers markets', Sustainability, Vol 2, pp 742-756.

Eden, S., Bear, C., and Walker, G. (2008), 'Understanding and (dis)trusting food assurance schemes: Consumer confidence and the 'knowledge fix', Journal of Rural Studies, Vol 24, pp 1-14.

Farmers' Guardian (2013), 'Diversification will continue to help farmers build business', Farmers' Guardian, 9 May 2013. 
Fernández-Olmos, M., and Díez-Vial, I. (2013), ‘Effect of firm’s resources on international diversification: An application in the Iberian Ham industry', European Management Journal, Vol 31, pp 196-208.

Grande, J., Madsen, E.L., and Borch,O.D. (2011),'The relationship between resources, entrepreneurial orientation and performance in farm-based ventures', Entrepreneurship and Regional Development, Vol 23, pp 89-111.

Grant R.M. (2010), Contemporary Strategy Analysis, $7^{\text {th }}$ edition, Malden: Blackwell.

Hansson, H., Ferguson, R., Olofsson, C., and Rantamäki-Lahtinen, L. (2013), 'Farmers' motives for diversifying their farm business - The influence of family', Journal of Rural Studies, Vol 32, pp 240-250.

Hingley, M.K. (2005), 'Power imbalance in UK agri-food supply channels: learning to live with the supermarkets?', Journal of Marketing Management, Vol 21, No 1-2, pp 63-88.

Hinrichs, C.C. (2000), 'Embeddedness and local food systems: notes on two types of direct agricultural market', Journal of Rural Studies, Vol 16, No 3, pp 295-303.

Hoaglin, D.C., Light, R.J., McPeek, B., Mosteller, F., and Stoto M.A. (1982), Data for decisions: Information strategies for policymakers, Cambridge, MA: Abt Books.

Huberman, M., and Miles, M.B. (2002), The Qualitative Researcher's Companion, Thousand Oaks: Sage.

Kirwan, J. (2006), 'The interpersonal world of direct marketing: Examining conventions of quality at UK farmers' markets', Journal of Rural Studies, Vol 22, pp 301-312.

La Trobe, H. (2001), 'Farmers' markets: consuming local rural produce', International Journal of Consumer Studies, Vol 25, No 3, pp 181-192.

Maye, D. (2013), 'Moving alternative food networks beyond the niche', International Journal of Sociology of Agriculture and Food, Vol 20, No 3, pp 383-389.

McElwee, G. and Bosworth, G. (2010), 'Exploring the strategic skills of farmers across a typology of farm diversification approaches', Journal of Farm Management, Vol 13, No 12, pp 819-838.

McInerney, J. and Turner, M. (1991), Performance and Prospects in Farm Diversification, Exeter: Agricultural Economics Unit Publication. 
McNally, S. (2001), 'Farm diversification in England and Wales - what can we learn from the farm business survey?' Journal of Rural Studies, Vol 17, No 2, pp 247-257.

Meert, H., Van Huylenbroeck, G., Vernimmen, T., Bourgeois, M., and Van Hecke, E. (2005), 'Farm household survival strategies and diversification on marginal farms, Journal of Rural Studies, Vol 21, No 1, pp 81-97.

Mintel (2014), Food and Drink Retailing - UK - March 2014, www.oxygen.mintel.com.

Morell I.A., and Brandth, B. (2007), 'Family and gender in the transformation of the countryside', Journal of Comparative Family Studies, Vol 38, No 3, pp 371-377.

Northcote, J. and Alonso, A. (2011), 'Factors underlying farm diversification: The case of Western Australia's olive farmers', Agriculture and Human Values, Vol 28, pp 237-246.

Paddison, A. and Calderwood, E. (2007), 'Rural retailing: a sector in decline?' International Journal of Retail and Distribution Management, Vol 35, No 2, pp 136-155.

Patton, M. Q., (2002), Qualitative Research \& Evaluation Methods, Sage Publications,

Thousand Oaks, London.

Phelan, C., and Sharpley, R. (2012), 'Exploring entrepreneurial skills and competencies in farm tourism', Local Economy, Vol 27, pp 103-118.

Schjoedt, L., and Shaver, K.G. (2007), 'Deciding on an entrepreneurial career: A test of the pull and push hypotheses using the panel study of entrepreneurial dynamics data', Entrepreneurship Theory and Practice, Vol 31, No 5, pp 733-752.

Scottish Government (2013), Economic Report on Scottish Agriculture 2013, Edinburgh: Scottish Government Publications.

Simon, H.A. (1959), 'Theories of Decision-Making in Economics and Behavioral Science', The American Economic Review, Vol 49, pp 253-283.

Timmons, J.A. (1999), New venture creation: entrepreneurship for the 21 st century $\left(5^{\text {Th }}\right.$ Ed), Burr Ridge: McGraw-Hill.

Turner, M., Whitehead, D., Barr, D., Fogerty, M., Errington, A., Lobley, M., and Reid, M. (2003) Farm diversification activities: benchmarking study 2002 to DEFRA University of Exeter and University of Plymouth. 
Vik, J., and McElwee, G. (2011), 'Diversification and the Entrepreneurial Motivations of Farmers in Norway', Journal of Small Business Management, Vol 49, pp 390-410.

Weatherall, C., Tregear, A. and Allinson, J. (2003), 'In search of the concerned consumer: UK public perceptions of food, farming and buying local', Journal of Rural Studies, Vol 19, No 2, pp 233-244.

Welpe, I. M., Spörrle, M., Grichnik, D., Michl, T., and Audretsch, D. B. (2012). Emotions and Opportunities: The Interplay of Opportunity Evaluation, Fear, Joy, and Anger as Antecedent of Entrepreneurial Exploitation. Entrepreneurship Theory and Practice, Vol 36, pp 69-96.

Wilson, A. (2012), Marketing Research: An Integrated Approach, $2^{\text {nd }}$ edition, Harlow: Pearson. Yin, R. (2008), Case study research: Design and methods: Sage publications, INC.

Zahra, S.A., (2007), 'Contextualizing theory building in entrepreneurship research', Journal of Business Venturing, Vol 22, pp 443-452.

Zerbe, N. (2010), 'Moving From Bread and Water to Milk and Honey: Framing the Emergent Alternative Food Systems', Humboldt Journal of Social Relations, pp 4-29. 
Tables.

Table 1: Family farm characteristics maintenance by diversification typology (researchers' elaboration)

\begin{tabular}{|c|c|c|c|c|c|c|}
\hline & $\begin{array}{l}\text { Ownership and } \\
\text { control by Family }\end{array}$ & $\begin{array}{l}\text { Ownership passed } \\
\text { by generation }\end{array}$ & $\begin{array}{l}\text { Labour provided } \\
\text { by the family }\end{array}$ & $\begin{array}{l}\text { Capital provided by } \\
\text { family }\end{array}$ & $\begin{array}{l}\text { Income is farming } \\
\text { related }\end{array}$ & $\begin{array}{l}\text { Family lives } \\
\text { on farm }\end{array}$ \\
\hline $\begin{array}{l}\text { Reducing farm holding } \\
\text { (selling land or part of land) }\end{array}$ & No & No & No & No & No & Possibly \\
\hline $\begin{array}{l}\text { Property development } \\
\text { (retaining but renting land to be } \\
\text { run by another party) }\end{array}$ & No & Yes & No & No & No & Possibly \\
\hline $\begin{array}{l}\text { New business activities } \\
\text { (deriving from natural resources } \\
\text { or not farm relates) }\end{array}$ & Yes & Yes & Yes & Yes & No & Yes \\
\hline $\begin{array}{l}\text { Diversifying farm business } \\
\text { (related to farm production) }\end{array}$ & Yes & Yes & Yes & Yes & Yes & Yes \\
\hline $\begin{array}{l}\text { Diversifying income } \\
\text { (pluriactivity) }\end{array}$ & Yes & Yes & No & Yes & No & Yes \\
\hline
\end{tabular}


Table 2: Informant Farmer Profiles

\begin{tabular}{|c|c|c|c|c|c|}
\hline Farmer & Age & $\begin{array}{l}\text { Family } \\
\text { Business }\end{array}$ & Core Product/ acreage & Diversification & $\begin{array}{l}\text { Entrepreneurial } \\
\text { motivations, practice } \\
\text { and outcomes }\end{array}$ \\
\hline Bill & 54 & Yes & $\begin{array}{l}\text { Organic fruit and vegetables } \\
110 \text { acres }\end{array}$ & $\begin{array}{l}\text { Farmers market } \\
\text { Farm shop } \\
\text { E-commerce }\end{array}$ & $\begin{array}{l}\text { Yes } \\
\text { Investment and good risk } \\
\text { evaluation } \\
\text { Good risk outcomes and } \\
\text { growth } \\
\text { Innovation }\end{array}$ \\
\hline Helen & 47 & Yes & $\begin{array}{l}\text { Soft fruit and jam } \\
320 \text { acres }\end{array}$ & $\begin{array}{l}\text { Farmers market } \\
\text { Farm shop }\end{array}$ & $\begin{array}{l}\text { Yes } \\
\text { Investment and good risk } \\
\text { evaluation } \\
\text { Good income outcomes } \\
\text { and growth }\end{array}$ \\
\hline John & 53 & Yes & $\begin{array}{l}\text { Free range poultry } \\
135 \text { acres }\end{array}$ & $\begin{array}{l}\text { Farmers market } \\
\text { Farm shop }\end{array}$ & $\begin{array}{l}\text { Yes } \\
\text { Good risk outcomes and } \\
\text { growth } \\
\text { Innovation }\end{array}$ \\
\hline Kathy & 46 & Yes & $\begin{array}{l}\text { Beef - fresh meat and } \\
\text { burgers } \\
315 \text { acres }\end{array}$ & Farmers market & $\begin{array}{l}\text { No } \\
\text { Access and Ease } \\
\text { Poor risk outcomes }\end{array}$ \\
\hline Alistair & 44 & Yes & $\begin{array}{l}\text { Fruit farm } \\
250 \text { acres }\end{array}$ & $\begin{array}{l}\text { Farm shop } \\
\text { e-commerce }\end{array}$ & $\begin{array}{l}\text { Yes } \\
\text { Investment and good risk } \\
\text { evaluation } \\
\text { Good risk outcomes and } \\
\text { growth } \\
\text { Innovation }\end{array}$ \\
\hline Joe & 56 & Yes & $\begin{array}{l}\text { Livestock- Beef, lamb, pork } \\
220 \text { acres }\end{array}$ & Farmers market & $\begin{array}{l}\text { No } \\
\text { Access and Ease } \\
\text { Poor risk evaluation and } \\
\text { outcomes }\end{array}$ \\
\hline Tom & 48 & Yes & $\begin{array}{l}\text { Beef- fresh meat and burgers } \\
119 \text { acres }\end{array}$ & $\begin{array}{l}\text { Farmers market } \\
\text { Limited farm shop }\end{array}$ & $\begin{array}{l}\text { No } \\
\text { Poor risk evaluation and } \\
\text { outcomes }\end{array}$ \\
\hline Will & 57 & Yes & $\begin{array}{l}\text { Venison } \\
300 \text { acres }\end{array}$ & Farmers market & $\begin{array}{l}\text { No } \\
\text { Access and Ease }\end{array}$ \\
\hline
\end{tabular}


Table 3: Key analysis themes

\begin{tabular}{|c|c|c|}
\hline Key Themes & Example Questions & Sample Verbatim \\
\hline \multicolumn{3}{|c|}{ Motivations for Diversification } \\
\hline Inequality & $\begin{array}{l}\text { Could we talk about working with } \\
\text { supermarkets, what kind of relationship } \\
\text { do you have with them? }\end{array}$ & $\begin{array}{l}\text { There's a power imbalance and you know, it's very unfair the margins that they can take } \\
\text { and how they can ask more and more from the farmers (John) }\end{array}$ \\
\hline Waste/ Risk & $\begin{array}{l}\text { Do traditional supply chains affect your } \\
\text { ways of working? }\end{array}$ & $\begin{array}{l}\text { I think farmers are well aware of the fact that they've got to take the risks of wind, weather } \\
\text { and all the rest of it but when they've got to start taking the risks from the supermarkets } \\
\text { that's when we need to stop (Tom) }\end{array}$ \\
\hline Ease/ access & $\begin{array}{l}\text { Why do you choose to sell through } \\
\text { farmers' markets? }\end{array}$ & $\begin{array}{l}\text { The farmers market is a good vehicle for us and what we do. I enjoy doing the farmers } \\
\text { markets it's a nice clientele honest people and I think the general public like to come and } \\
\text { speak to farmers (Will) }\end{array}$ \\
\hline $\begin{array}{l}\text { Poor risk } \\
\text { evaluation and } \\
\text { outcomes }\end{array}$ & $\begin{array}{l}\text { What part do farmer' markets play in your } \\
\text { business? }\end{array}$ & $\begin{array}{l}\text { For a long time we were just chasing turnover and not making any money - so you want to } \\
\text { get some reward for your effort (Kathy) }\end{array}$ \\
\hline \multicolumn{3}{|c|}{ Entrepreneurial diversification characteristics } \\
\hline Innovation & $\begin{array}{l}\text { Are there aspects of your business that } \\
\text { you've changed or are doing differently } \\
\text { since diversifying? }\end{array}$ & $\begin{array}{l}\text { We've moved some business online, people can order a mix of different boxes. Customers } \\
\text { can set different price levels as well so there should be one to fit most budgets. We're on } \\
\text { facebook and have our own blog so that helps word of mouth.(Bill) } \\
\text { The jam is becoming an important part of our business and we sell that to other shops now } \\
\text { and through box schemes and even online. (Helen) }\end{array}$ \\
\hline
\end{tabular}

\section{June 14}

